\title{
ФОРМУВАННЯ МОДЕЛІ УПРАВЛІННЯ ОРГАНІЗАЦІЙНОЮ КУЛЬТУРОЮ ПІДПРИЄМСТВ МЕРЕЖЕВИХ СТРУКТУР В КОНТЕКСТІ МАКРОТРЕНДІВ БІЗНЕСУ
}

\author{
Гевко Володимир Леонідович \\ кандидат економічнихнаук, доцент \\ народний депутат України \\ ORCID: 0000-0003-2716-8113 \\ hevkov475@gmail.com
}

\begin{abstract}
В статті розкрито теоретико-прикладні аспекти організаційної культури підприємств мережевих структур в сучасних умовах макротрендів бізнесу. Сформовано модель формування організаційної культури підприємства мережевих структур, яка з практичної точки зору включає сім етапів. Досліджено, що формування організаційної культури необхідно ідентифікувати за циклом функціонування підприємств мережевих структур на основі фаз зародження організаційної культури; становлення; фаза розквіту; фраза занепаду. Обгрунтовано, що при фрормуванні організаційної культури керівництву підприємству мережевих структур необхідно зосередити увагу на: відборі та навчанні персоналу з необхідними навичками; делегуванні повноважень і розширенні сфрери відповідальності; розвитку лідерства; створенні адекватної системи оцінки результатів роботи персоналу і системи винагород. На основі чого відзначено, що удосконалення існуючої організаційної культуру необхідно застосовувати в контексті таких умов: організація перебуває у стані кризи; в організацію прийшов новий лідер; організація є достатньо молодою або невеликою за розмірами; організаційна культура є слабкою. Доведено, що організаційна культура підприємств мережевих структур є системою, яка включає підсистеми, пов'язані тісними зв'язками прямого і зворотного характеру.
\end{abstract}

Ключові слова: організаційної культура підприємств, підприємства мережевих структур, модель фрормування організаційної культури, цикл функціонування підприємств мережевих структур.

DOI: https://doi.org/10.32845/bsnau.2019.3.19

Постановка проблеми. В умовах сучасних викликів потрібні рішучі дії, значні зусилля, ретельна організаційна робота для приведення виробничих відносин в системі функціонування підприємств мережевих структур. Важливою складовою системи забезпечення конкурентоспроможності підприємств мережевих структур має бути оптимізація соціальнотрудових відносин, формування й подальший прогресивний розвиток організаційної культури. Слід відзначити, що саме формування дієвої організаційної культури є інструментом забезпечення прогнозованого стратегічного розвитку мережевих підприємств та запорукою високої продуктивності праці працівників. Однією зі специфічних характеристик, що відрізняють підприємства мережевих структур є надзвичайна значущість людського фактору при досягненні цільового рівня економічної результативності з урахуванням організаційної компоненти.

Аналіз останніх досліджень і публікацій. Окреслена тематика виступає предметом наукових досліджень багатьох вітчизняних науковців. Зокрема, теоретичні аспекти наукової проблематики щодо формування організаційної культури підприємств мережевих структур досліджують такі вітчизняні науковці як С. Гриценко, Г.Дмитренко, О. Вівчар, О. Єрмакова, Т. Заславська, Г. Колодко, В. Кириченко, Н. Кирич, Б. Козирь, Т. Максименко, С. Оборська, Ю. Пахомов, Р. Ривкіна, 3. Шершньова, Е. Шарапова, К. Франкич та інш.

Метою cmammi $є$ формування моделі управління організаційною культурою підприємств мережевих структур в сучасних умовах макротрендів бізнесу.

Основні результати дослідження. Проведені дослідження засвідчують, що Складність і багатогранність проблеми управління організаційною культурою підприємства обумовлена специфічними рисами, різноманіттям складових ï̈ елементів і проявів. Організаційна культура підприємств мережевих структур - це складне соціальне явище, що формується усередині мережевої структури під впливом певних

чинників. У силу своєї соціальної природи працівник сильно відчуває вплив культури підприємницької структури. Разом 3 тим й особистість впливає на формування й зміну самої культури даних підприємств. Слід відзначити, що як і будь-яке соціальне явище, культура підприємств мережевих структур не існує без людського співтовариства. 3 одного боку, організаційна культура підприємства мережевих структур регулює всі відносини працівників у даному колективі - організації, з іншого боку - є продуктом цих відносин. Сформувавши організаційну культуру на базі своїх уявлень, установок, ціннісних орієнтацій, працівники тим самим визначили технологію, спосіб діяльності й існування мережевої структури. Організаційна культура підприємства мережевих структур формує відношення до праці, впливає на ступінь задоволеності працею, на особливості організації праці. Варто також наголосити на формуванні та розвитку культури підприємства в умовах децентралізації влади та нарозвиток культури місцевості $[1 ; 2]$.

Саме в таких умовах функціонування організаційна культура підприємства мережевих структур утворює стійку, спрямовану на тривалий строк мотивацію персоналу, орієнтовану на досягнення стратегічних цілей мережевої структури, що становить частину стратегічного управління. Крім цього на основі організаційної культури підприємств мережевих структур можна спільно виробити бачення мережі. Культура підприємств мережевих структур сприяє об'єднанню працівників, направляє поведінку співробітників даної організації, формуючи основні пріоритети, у рамках яких ця поведінка припустима. Неможливо залишити поза увагою те, що керівники успішно працюючих підприємств мережевих структур прагнуть створити таку організаційну культуру підприємницької мережі, яку людські ресурси підприємства не тільки сприймали б, але й дотримувалися її. Для цього необхідно посту- 
пово виховувати у працівників прагнення дотримуватися цінностей, норм і правил, прийнятих на підприємстві мережевих структур [3].

3 практичної точки зору варто відзначити, що на підприємстві мережевих структур існує подвійного регулювання організаційної культури, що безумовно вимагає врахування взаємного впливу декларованих культурних цінностей, норм та установок і реальної поведінки працівників, які $є$ носіями культури. 3 одного боку, культура підприємства мережевих структур формується під впливом його співробітників, з іншого, впливає на їх поведінку і взаємини [4, с. 48]. Звідси можна сказати, що існує принцип дуального регулювання, коли взаємозалежні дві субкультури: керівна ієрархія (соціальна сфрера), де роль вищого регулятора відводиться установкам персоналу вони впливають на цінності, а ті, у свою чергу, - на розвиток культури підприємства мережевих структур. А також культурна ієрархія, що зосереджена в основних функціональних сферах підприємства мережевих структур і в якій керівництво мережевої структури є вищим регулятором. Таким чином, організаційна культура підприємства мережевих структур являє собою важливий елемент системи, що володіє особливими характеристиками, пов'язаними з тим, що в культурі можна виділити складову безпосередньо пов'язану із впливом працівника - соціальну та складову, регламентовану функціональними сферами підприємства мережевих структур.

Отже, в процесі свідомого формування культури відбувається повна ідентифікація працівника із організацією, в результаті чого він не тільки розуміє цілі підприємства мережевих структур і наслідує моделі поведінки, а й повністю поділяє цінності даних підприємств, позитивно сприймає створені на їх основі процедури і артефакти. Вважаємо, що організаційна культура є достатньо інерційним об'єктом управління, адже досягнення кінцевої мети - підвищення ефективності на основі приведення ціннісних установок індивіда у відповідність до системи цінностей компанії - передбачає не просто поверхневий плив на діяльність працівника. Раціоналізація процесу управління розвитком організаційної культури підприємств мережевих структур проходить певні етапи, що представлені на рис. 1. На основі даного рис. 1 встановлено, що етапи процесу формування організаційної культури підприємства мережевих структур полягають у чіткій організації роботи мережевих структур, а також із врахуванням чинників внутрішнього і зовнішнього середовища. Вплив чинників створює формування функцій організаційної культури, засоби підтримки, формування організаційної культури та підвищення кваліфікації управлінських кадрів. За допомогою постійного вдосконалення та контролю відбувається реалізація моделі управління організаційною культурою підприємств мережевих структур.

Неможливо залишити поза увагою те, що кожен із запропонованих етапів процесу управління розвитком організаційної культури підприємств мережевих структур передбачає реалізацію конкретних робіт з організаційної культури. Фор- муючи організаційну культуру, керівництво повинне враховувати те, що організаційна культура насамперед сприяє ефективності управління персоналом. Саме тому, розглядаючи раціоналізацію процесу управління розвитком організаційної культури підприємств мережевих структур, потрібно орієнтуватись на ті чинники, які допомагають персоналу працювати з максимальною віддачею та користю, а не використовувати жорсткі правила і норми поведінки та орієнтацію на результат [5, с. 129-130].

Слід зазначити, що формування організаційної культури варто ідентифікувати і циклом функціонування підприємств мережевих структур: 1) зародження організаційної культури - відбувається в процесі створення даних підприємств, у цій фазі організаційна культура характеризується слабкістю і одноманітністю проявів, у великій мірі залежить від ціннісних установок засновників; 2) фаза становлення характеризується утворенням, урізноманітненням елементів організаційної культури, у цій фазі на якісно-кількісні характеристики організаційної культури справляють не тільки засновники, але й керівники підприємств мережевих структур; 3) фаза розквіту - у цій фазі організаційна культура характеризується максимальним проявом таких характеристик як сила, адаптивність, у другій та третій фазі розвитку процес формування організаційної культури потребує зваженого і цілеспрямованого втручання з боку керівництва; 4) фраза занепаду наступає, якщо підприємства мережевих структур знаходиться у фазі кризи; для активізації організаційної культури, посилення її позитивної ролі у системі менеджменту необхідно проводити організаційні зміни із залученням відповідних фахівців [6].

Складність дійсної ситуації в процесі формування організаційної культури підприємств мережевих структур полягає в тому, що на зміну її стану діє не один, а декілька факторів, які можуть бути як внутрішніми, так і зовнішніми. У зв'язку із цим управління процесом формування організаційної культури є надзвичайно складним завданням.

Одразу ж зауважимо, що при формуванні організаційної культури керівництву підприємству мережевих структур слід зосередити увагу на: 1) відборі потенційно лояльного персоналу; 2) навчанні персоналу необхідним навикам; 3) делегуванні повноважень і розширенні сфери відповідальності; 4) розвитку лідерства, як необхідної умови формуванні організаційної культури; 5) створенні адекватної системи оцінки результатів роботи персоналу і системи винагород.

Для підвищення ефективності процесу формування організаційної культури обов'язковою умовою $є$ його узгодження із довгостроковими цілями та стратегією підприємств мережевих структур [7, с. 123]. Внесення змін в існуючу організаційну культуру полегшується, якщо виконуються такі умови: 1) організація перебуває у стані кризи; 2) в організацію прийшов новий лідер; 3) організація є достатньо молодою або невеликою за розмірами; 4) організаційна культура є слабкою [8]. 


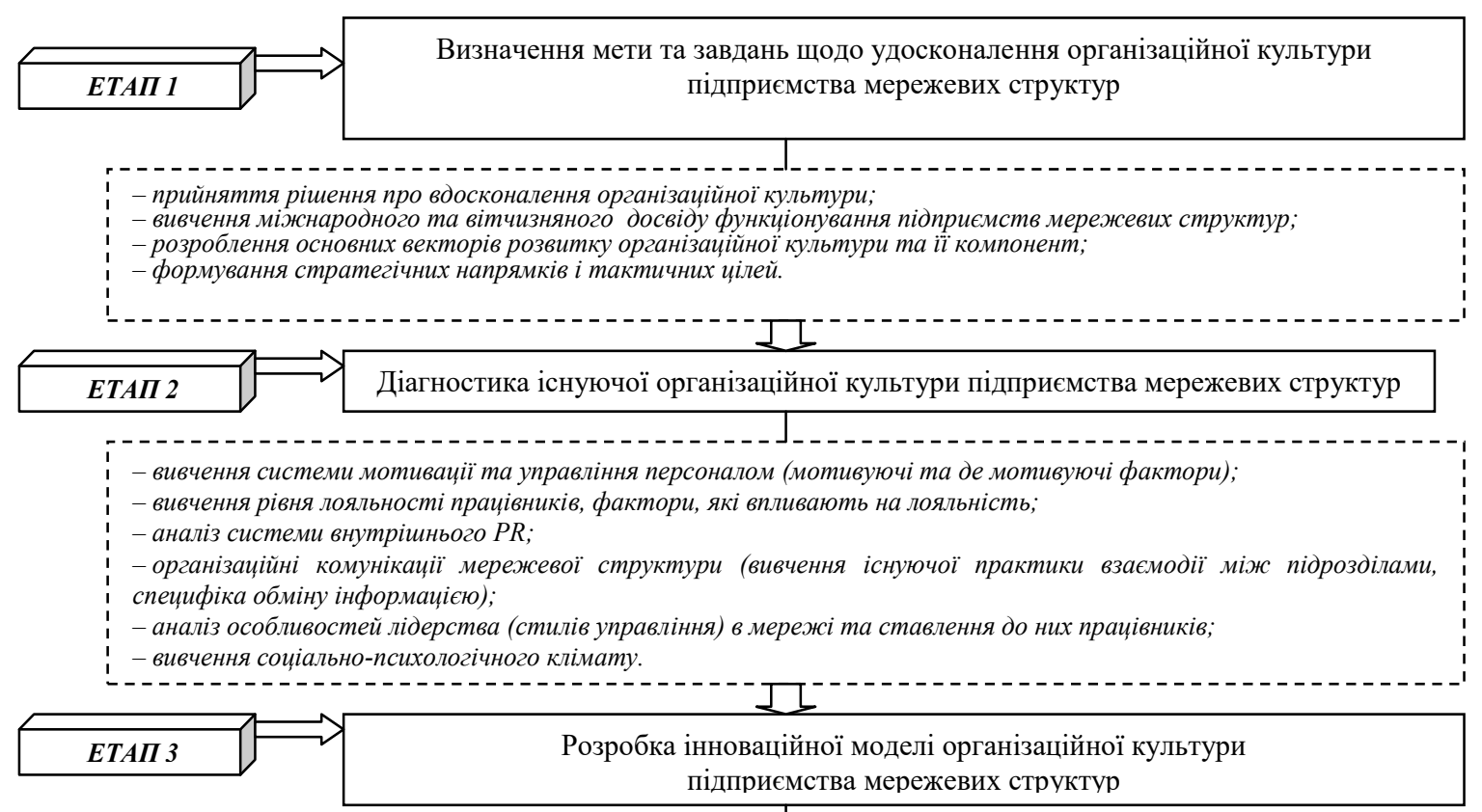

- проведення співбесід з керівниками, які проєктують організаиійну культуру;
- розробка єдиного бачення майбутньої організаиійної культури;
-створення концепії внутрішнього РR (корпоративні документи, правила, процедури, символіка).
ЕТАП 4
Документальне оформлення та прийняття рішення

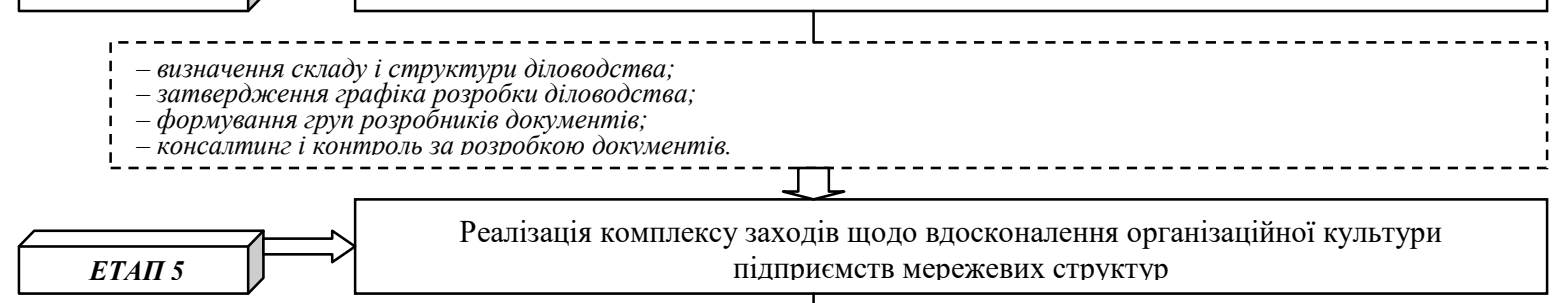

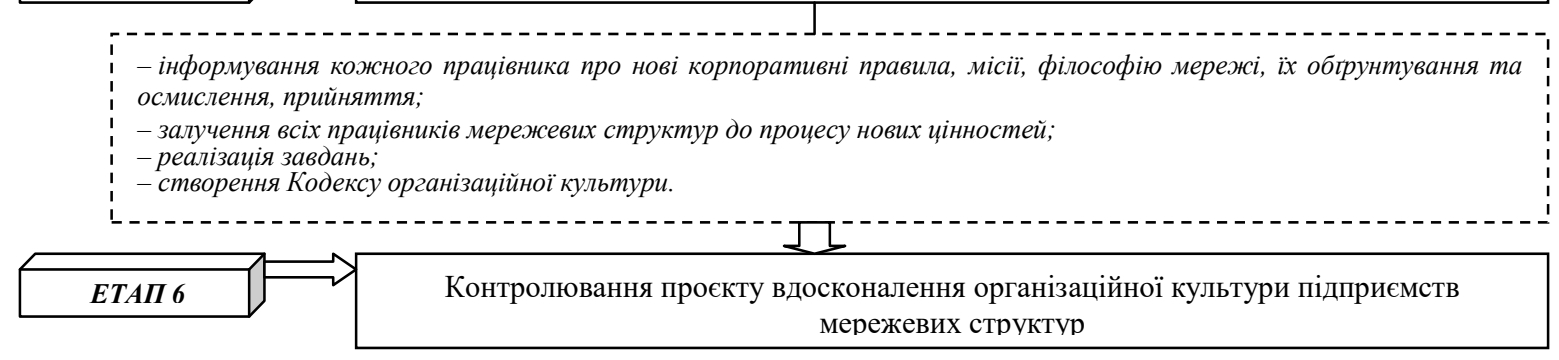

-оцінка стану впроваджених змін;
-попередня оиінка змін організаиійної культури;
-контроль якісних та кількісних параметрів зміни організаційної культури.
Оцінка ефективності проектних рішень вдосконалення організаційної культури
пТідприємств мережевих структур

Власна розробка автора.

Рис. 1. Модель формування організаційної культури підприємства мережевих структур

Висновки. На основі дослідженого, слід відзначити, що організаційна культура підприємств мережевих структур становить сукупність формальних і неформальних взаємовідносин, матеріальних і нематеріальних цінностей, правил та способів, дій і комунікацій між усіма учасниками діяльності підприємства, що формують ключові компетенції і забезпечують довгострокову конкурентоспроможність даних підприєм- 
ницьких структур. Підприємства мережевих структур забезпечують сукупність дій, необхідних для досягнення поставлених цілей і погодженість зв'язків між усіма суб'єктами мере- жевої взаємодії; реалізує дифреренційований підхід до роботи, відповідно до чого мережі виступають як механізм інтеграційної політики.

\section{Список використаної літератури}

1. Попадинець Н.М. Зарубіжний досвід децентралізації сфери культури та можливості його використання в Україні. Соціально-економічні проблеми сучасного періоду України. 2017. Вип. 4(126). С. 83-87.

2. Попадинець Н. М. Напрями реформування сфрери культури в умовах секторальної децентралізації. Регіональна економіка. 2017. №3 (84). С. 116-122.

3. Устинов Р. Г. Обгрунтування взаємозв'язку культури підприємства та його конкурентоспроможності. Науковий журнал Менеджер. Вісник Донецького державного університету управління. Серія «Економіка». 2018. №4(81). С. 85- 92.

4. Вівчар О.І., Ціх Г.М. Домінуючі тенденції та сучасні проблемні аспекти соціогуманітарного чинника економічної безпеки підприємницьких структур ОСББ. Матеріали Міжнародної науково-практичної конференції «ОСББ: досвід, виклики, перспективи». ТНТУ імені Івана Пулюя. Тернопіль, 30 січня 2017 р. С. 47-48 .

5. Гайдай Ю. В. Формування організаційної культури підприємств торгівлі : дис. ... канд. екон. наук : 08.00.04. Київ, 2014. 250 c.

6. Харчишина О. В. Формування організаційної культури в системі менеджменту підприємств промисловості : монографрія. Житомир: Вид-во Житомирського державного університету ім. І Франка. 2011. 289 с.

7. Кириченко В. Прогнозування поведінки персоналу в період змін на підприємстві. Соціальна психологія. 2004. № 2 (4). С. 122-133.

8. Проблеми теорії і практики менеджменту : навчал.-метод. посібн. / Андрушків Б. М. та ін. Тернопіль: Вид. ТзОВ «Терно-Графф», 2009. 312 c.

1. Popadinets, N.M. (2017). Zarubizhnyy dosvid detsentralizatsiyi sfery kul'tury ta mozhlyvosti yoho vykorystannya v Ukrayini [Foreign experience of decentralization of culture and its use in Ukraine]. Sotsialno-ekonomichni problemy suchasnoho periodu Ukrayiny - Socio-economic problems of the modern period of Ukraine, 4 (126), 83-87.

2. Popadinets, N.M. (2017). Napryamy reformuvannya sfery kul'tury v umovakh sektoralnoyi detsentralizatsiyi [Areas of reforming the sphere of culture in the context of sectoral decentralization]. Rehionalna ekonomika - Regional economy, 3 (84), 116-122.

3. Ustinov, R.G. (2018). Obhruntuvannya vzayemozvyazku kultury pidpryyemstva ta yoho konkurentospromozhnosti [Justification of interrelation of enterprise culture and its competitiveness]. Naukovyy zhurnal Menedzher. Visnyk Donetskoho derzhavnoho universytetu upravlinnya. Seriya «Ekonomika» - Scientific Journal Manager. Bulletin of Donetsk State University of Management. Economy series, 4 (81), 85- 92.

4. Ovchar, O.I, Tsih G.M., (2017). Dominuyuchi tendentsiyi ta suchasni problemni aspekty sotsiohumanitarnoho chynnyka ekonomichnoyi bezpeky pidpryyemnytskykh struktur OSBB [Dominant tendencies and current problematic aspects of socio-humanitarian factor of economic security of condominium business structures]. Ivan Pulyuy TNTU. Ternopil, January 30, 47-48.

5. Gaidai, Y.V. (2014). Formuvannya orhanizatsiynoyi kultury pidpryyemstv torhivli [Formation of organizational culture of trade enterprises]. diss. ... Cand. econom. Sciences: 08.00.04. Kyiv.

6. Kharchyshina, O.V. (2011). Formuvannya orhanizatsiynoyi kul'tury v systemi menedzhmentu pidpryyemstv promyslovosti [Formation of organizational culture in the management system of industrial enterprises]. Zhytomyr: View of Zhytomyr State University. And Franco.

7. Kirichenko, V. (2004). Prohnozuvannya povedinky personalu v period zmin na pidpryyemstvi [Prediction of personnel behavior in the period of changes in the enterprise]. Sotsialna psykholohiya - Social Psychology, 2 (4), 122-133.

8. Andrushkiv, B.M. (2009) Problemy teoriyi i praktyky menedzhmentu : navchal.-metod. posibn [Problems of management theory and practice: educational method]. Ternopil: View. Terno-Graf Ltd.

\section{Gevko V. L. PhD in Economics, Associate Professor \\ Formation of the model of management of organizational culture of enterprises of network structures in the context of macrotrends of business}

Modern scientific research points to the fact that without properly formed organizational culture of enterprises at network structures it is impossible to achieve a high level of economic efficiency. In this context, the formation of a model the organizational culture of enterprises of network structures and the isolation of structural elements is quite relevant. Theoretical and applied aspects of organizational culture of enterprises at network structures in modern transformational conditions are investigated. A model of forming the organizational culture of an enterprise at network structures has been formed, which from a practical point of view includes seven stages, taking into account the effectiveness of the implemented measures. It has been researched that the formation of organizational culture should be identified by the cycle of functioning of enterprises at network structures based on the phases of the emergence of organizational culture; becoming; flowering phase; phase of decline. It is substantiated that in the formation of organizational culture of management the enterprise at network structures should focus on: selection and training of personnel with the necessary skills; delegation of powers and expansion of responsibility; leadership development; creating an adequate system for evaluating the performance of staff and the remuneration system. On this basis, it is noted that the improvement of the existing organizational culture should be applied in the context of following conditions: the organization is in crisis; a new leader has joined the organization; the organization is young or small enough; organizational culture is weak. It is proved that the organizational culture of enterprises at network structures 
is a system that includes subsystems connected by close links of the forward and reverse nature. Thus, the main provisions of the scientific article will allow domestic enterprises at network structures to apply the model of formation the organizational culture of enterprises at network structures based on the phased implementation and provision of conditions for their reproduction on a large scale.

Key words: organizational culture of enterprises, enterprises of network structures, model of formation of organizational culture, cycle of functioning of enterprises of network structures.

Дата надходження до редакції: 29.08.2019 р. 